\title{
Various Corrective Feedback Types in Collaborative vs. Individual Writing Conditions
}

\section{Maryam Soleimani ${ }^{*}$, Sima Modirkhamene ${ }^{2}$}

\footnotetext{
* Correspondence:

m.soleimani.1361@gmail.com

${ }^{1}$ Department of English Language

Teaching, Farhangiyan University,

Urmia, West Azerbaijan, Iran

${ }^{2}$ Department of English, Urmia

University, Iran
}

Received: 18 February 2020

Revision: 6 May 2020

Accepted: 13 May 2020

Published online: 20 September 2020

\begin{abstract}
One of the important issues in EFL instruction is the idea of eliminating students' linguistic errors through providing corrective feedback (CF). Accordingly, this study investigated the effect of various CF types (i.e., comprehensive, selective, and no feedback) on advanced EFL learners' writing in different writing conditions (i.e., individual \& collaborative). 132 EFL advanced learners aged from 14-20 were considered as the main participants. Learners were divided into 6 groups (i.e., three individual and three collaborative writing conditions). Furthermore, each writing condition included three groups with selective, comprehensive, and no correction orientations. Data collection tools and procedures encompassed an institutionalized Placement Test, pre-test, and post-test. The treatment that lasted for nine sessions was followed by a post-test. Data were submitted to a series of ANOVA tests with follow up pair-wise comparisons and independent-samples t-tests. Findings indicated that: (1) CF, especially selective one, was more effective in enhancing learners' writing accuracy, and (2) members of the collaborative writing groups outperformed those in the individual ones in terms of their writing accuracy development. The theoretical and practical implications are discussed in relation to enhancing writing accuracy of the learners.
\end{abstract}

Keywords: corrective feedback, collaborative writing, selective feedback, comprehensive feedback, EFL learners 


\section{Introduction}

In learning something new, there is always the possibility of making mistakes. In the history of language acquisition and learning, learners have encountered a lot of difficulties in the learning process. One of the most important difficulties is omitting students' linguistic errors. When errors occur in the second language acquisition, teachers encounter another problem called error correction which always confuses teachers since they do not know whether this error should be corrected or not, and if so, when is the best time and what is the best way to correct it. Whether and how CF can help students to become good writers have been of great interest for researchers (Chandler, 2003; Ferris, 2010).

Since good writing entails the acquisition of various linguistic abilities, including grammatical accuracy, lexicon, syntax, and planning strategies like organization, style and rhetoric, writing instruction is especially important in English as a Foreign Language (EFL) classes (Aydin \& Yildiz, 2014). The ability to write effectively is becoming more significant in today's communication and academic settings, and, therefore, improving the writing ability of the learners is assuming an important part in L2 language education (Ghoorchaei, Tavakoli, \& Ansari, 2010).

As regards effective writing pedagogy, one type of feedback that EFL writing teachers provide is CF which is defined as "any indication to the learner that his or her use of the target language is incorrect" (Lightbown \& Spada, 2006, p. 197). Although the effectiveness of CF is under question (Truscott, 1996; Truscott \& Hsu, 2008), many L2 writing teachers believe that CF is effective in improving their learners' L2 writing accuracy (Brown, 2007; Ellis et al., 2008; Hyland \& Hyland, 2006; Sheen, 2007) and there is a need for its use (Van Beuningen, 2010; Van Beuningen, De Jong, \& Kuiken, 2012). Thus, written CF is an important part of second language writing because it provides teacher-student interaction in L2 writing class (Ferris, Pezone, Tade, \& Tinti, 1997).

Indeed, inspired basically by the Sociocultural Theory (SCT) of language learning, the current view of language learning and teaching emphasizes the use of collaborative work (i.e., pair and group) in the language classroom (Batstone, 2010; Lantolf, 2000; Shehadeh \& Coombe, 2010). Collaborative Writing (CW) is believed to enhance language in general and writing in particular in L2 learning (Storch, 2005; Villamil \& de Guerrero, 1998). According to Vygotsky (1978), social interaction between partners mediates the learning process and socially rich conditions should be provided for learners for better cognitive development. As Lantof (2000) states, the talk generated during the co-construction and revision of a piece of writing helps researchers to access the learners' cognitive processes and investigate the effect of that talk on language learning as reflected in the students' writing. SCT emphasizes the importance of interaction with peers. In other words, according to Vygotsky's (1978) Zone of Proximal Development (ZPD), through mediation and interaction among learners in the writing class, writing skill can develop.

\subsection{Statement of the Problem}

The literature on written CF is teeming with contradictions with some studies emphasizing the positive effects of written CF on learners' intake and with some other studies rejecting its usefulness. The current status quo of English writing skill at an adequate level indicates a great deficiency of the learners in their writing proficiency. The main difficulties which make learners poor writers in the classrooms can include problems originating from the learning environment, the teacher, content knowledge, affective factors, materials and contextual factors (Koosha \& Yakhabi, 2013).

In addition, most of the teachers do not know how to encourage learners to write and get them to work collaboratively which can be enjoyable and motivating. Moreover, they are short of knowledge on which errors to correct, how to correct (i.e., which methods to use), and when to provide CF on the errors. Regarding CW, the number of the studies investigating the advantages of CW is rare, especially in the Iranian context. Storch (2005) states that "although pair and group work are commonly used in language classrooms, very few studies have investigated the nature of such collaboration when students produce a jointly written text" (p. 153).

In sum, both teachers and students feel the need for the use of CF in EFL learners' writing (Van Beuningen, 2010; Van Beuningen, De Jong, \& Kuiken, 2012). Therefore, there is a dire need for further research to shed more light on this fledgling concept of differential effect of various types of written CF. Accordingly, this study was an attempt to assess student uptake of corrections received through various forms of intervention, that is, direct comprehensive feedback, direct selective feedback, and no feedback on texts written in different conditions, that is, individually and collaboratively. Thus, the following research hypotheses and questions were formulated. 


\subsection{Research Questions}

The researchers formulated the following research questions:

1. Is there a significant difference among patterns of CF (direct selective, direct comprehensive, and no correction) in terms of their effect on writing accuracy of EFL learners in individual writing conditions?

2. Is there a significant difference among patterns of $\mathrm{CF}$ (direct selective, direct comprehensive, and no correction) in terms of their effect on writing accuracy of EFL learners in collaborative writing conditions?

3. Is there a difference between collaborative and individual writings at the post-test?

\subsection{Research Hypotheses}

The research hypotheses are as follows:

1. There is no significant difference among patterns of CF (direct selective, direct comprehensive, and no correction) in terms of their effect on writing accuracy of EFL learners in individual writing conditions.

2. There is no significant difference among patterns of CF (direct selective, direct comprehensive, and no correction) in terms of their effect on writing accuracy of EFL learners in collaborative writing conditions.

3. There is no difference between collaborative and individual writings at the post-test.

\section{Literature Review}

According to Godwin-Jones (2018), nowadays emphasis in studies on L2 writing is one the stages of a writing project viewed as a process not a product. Students improve their writings through teacher and peer feedback. Thus, writing is seen as an interactive process involving a negotiation with readers (Zheng \& Warschauer, 2017). Thus, linguistic accuracy, clarity of presentation, and organization of ideas are all important factors in enhancing the efficacy of the communicative act, since they supply the clue for interpretation (Araghi \& Sahebkheir, 2014; Ashoori Tootkaboni \& Khatib, 2014; Salimi \& Ahmadpour, 2015). Accordingly, while the global perspective of content and organization need to be focused on and given appropriate attention, it is also most important to present a product which does not suffer from illegible handwriting, numerous spelling errors, faulty punctuation, or inaccurate structure, any of which may render the message unintelligible (Celce-Murcia, 2001).

According to Kahyalar and Y1lmaz (2016), CF in second language acquisition is used to refer to "responses to the errors in learners' second language productions, and giving effective CF is a central concern for teachers of writing" (p. 148). Providing feedback as an important part of EFL writing instruction is of great significance for both teachers and students. Feedback is perhaps the most widely used method for reacting to student writing. Teachers view it as spending a lot of time on learners' writing; however, for students, error correction is the most important part that will lead to their success as writers (Ashoori Tootkaboni \& Khatib, 2014; Ferris, 2003; Ghandi \& Maghsoudi, 2014; Kahyalar \& Yilmaz, 2016). However, the usefulness of error correction and its contribution to the development and improvement of writing accuracy continues to be under question (Ferris, 1999; Chandler, 2003; Truscott, 1996; Truscott \& Hsu; 2008).

A number of studies have claimed that CF has significant effects on EFL students' writing (Ahmadi Shirazi \& Shekarabi, 2014; Bitchener, 2008; Karimi, 2014; Maleki \& Eslami, 2013; Zarei \& Rahnama, 2013). In spite the fact that the effectiveness of oral CF is well-established (Li, 2010; Lyster \& Saito, 2010; Mackey \& Goo, 2007), and also a number of theoretical Second Language Acquisition (SLA) insights predict that written CF can enhance L2 development, the usefulness and efficacy of written error correction is a topic of considerable debate (Ferris, 1999, 2004; Truscott, 1996; 1999, 2007; Truscott \& Hsu, 2008). Regarding the efficacy of CF in EFL writing classes, there are two general approaches toward written error correction (i.e., comprehensive vs. selective) in the literature (Ellis, 2009; Van Beuningen, 2010). The comprehensive/unfocused approach involves the teachers correcting all errors in a learner's text without considering the error category. On the other hand, the selective/focused approach focuses on specific linguistic features only, leaving all other errors outside of the focus domain uncorrected.

There are some research studies regarding the effectiveness of either approach. Through comprehensive CF, the students' attention is drawn toward errors in writing, and also to new features of the target language, therefore, promoting more effective language learning (Corpuz, 2011). Some researchers have found evidence that correction of all errors can reduce the number of errors (Lalande, 1982) and enhance the accuracy of the texts (Van Beuningen, De 
Jong, \& Kuiken, 2008, 2012); others, on the other hand, have called for selective/focused correction of specific error types (Ferris, 2006, Van Beuningen, 2010).

Collaborative learning (CL), on the other hand, involves two or more people interacting with each other to enhance learning (Dillenbourg, 1999). Recent years have witnessed a significant growth of research on CW in L2 classroom (Li \& Zhu, 2017; Mozaffari, 2017; Wu, 2015; Zhang, 2018). CW is supported by cognitive and sociocultural theories of L2 learning. In other words, Long's (1996) interaction hypothesis, according to cognitive view, suggests that negotiation for meaning and form can increase and facilitate L2 learning. From Vygotsky's (1978) sociocultural perspective, language learning is a socially mediated process through which learners construct knowledge (Du, 2018). Constructivism, in the same vein, emphasizes the student-centered learning (Cheek, 1992; Yager, 1991). As noted in Hansen and Liu (2005), and substantiated by others (Storch, 2005; Swain \& Lapkin, 1998), peer editing leads to more meaningful revision, as these revisions are superior in vocabulary, organization, and content. Studies by GoussevaGoodwin (2000) and Storch (2005) further found that advanced English as a Second Language (ESL) learners' collaborative essay grades were higher than those done independently and tended to have greater grammatical accuracy.

Researchers have reported numerous benefits of the use of collaboration in wiring such as observing how other learners think and modeling their peers' thinking strategies and writing styles (Dale, 1994). In addition, collaboration enhances the sense of camaraderie and confidence (Fung, 2011). However, one should keep in mind that learners sometimes get reluctant to engage in co-authoring (McDonough, 2004); therefore, care should be taken by the teachers in guiding L2 learners to participate appropriately in collaborative works. Peer feedback may provide more social or affective support than teacher feedback; learners may find it less threatening (Lee, 2015). Peer feedback can "enhance a sense of audience and text ownership" (Lee, 2015, p. 2), leading students to take their role seriously, creating the potential for reflection and discussion on language issues.

In spite of recommendations for the use of CW (Lee, 2015; Tocalli-Beller, 2003), it is not clear for writing instructors what actually takes place during collaboration. The primary interviews with some of the teachers by the researcher herself revealed that few teachers conduct $\mathrm{CW}$ in their classes due to the shortage of time. Most of the teachers stated that it is time-consuming and creates a disorderly situation in the classroom. Moreover, learners do not know how to write collaboratively since it is not applied in the classes at all. Some writing instructors also claim that it is not logical to ask learners to work collaboratively because not everyone is able to work with others who have different opinions, thus, conflict may occur (Stewart, 1988).

However, the studies by Storch (2005) and Storch and Wigglesworth (2007) that investigated CW in L2 found significant differences in favor of CW for grammatical accuracy. Indeed, inspired basically by the SCT model of language learning, the current view of language learning and teaching emphasizes instruction where collaborative work is at the center of the language classroom (Batstone, 2010; Lantolf, 2000; Shehadeh \& Coombe, 2010). Therefore, more research into what happens in both pair and group writing situations is needed to determine its effectiveness on the accuracy of the texts produced and the types of feedback learners may get from each other.

\section{Methodology}

\subsection{Design of the Study}

The researchers adhered to an intact group design bringing the research to light as a quasi-experimental type of enquiry. In the current investigation, 6 advanced classes were randomly selected and assigned into two groups, namely, collaborative and individual writing groups (each one including three classes). Each group received various feedback types (i.e., direct comprehensive feedback, direct selective feedback, and no feedback), and was given the same preand post-test. Pre-test was administered in order to make sure that the groups were homogeneous in terms of language ability (i.e., writing accuracy) before the treatment; and post-test was used to measure the extent to which treatment was effective.

\subsection{Participants}

A total of 132 advanced female EFL learners formed the main participants. They all ranged in age from 14-20 and were learning EFL in an English Language Institute. By means of an institutionalized placement test, 6 advanced classes including 22 participants in each class were selected and the classes were assigned into two main groups writing either collaboratively or individually. Moreover, each main writing condition (i.e., collaborative and 
individual) was divided into three groups receiving comprehensive $\mathrm{CF}$, selective $\mathrm{CF}$ and no feedback at all, that is, following Truscott's (1996) view, no correction of grammar errors. The participants had 3-year experience of learning English at secondary school and institute(s).

\subsection{Instruments}

In the current study, the following instruments were employed in data collection process:

1) English Language Institute Placement Test

2) Pre-tests

3) Post-test

\subsubsection{English Language Institute Placement Test}

It is a highly valid and reliable proficiency test institutionalized by Iran Language Institute and used at the beginning of each term as the placement test. It includes items on grammar (60) and vocabulary (60) followed by an interview. It served the purpose of homogenizing the participants in terms of language proficiency at the outset of the study.

\subsubsection{Pre-tests}

Having established homogeneity among the groups in terms of their language proficiency, the researchers selected a topic covered in the students' books, namely, Advanced Student's Book for which the learners were required to write a composition. Learners were asked to write a composition within a word limit of at least 250 in 45 minutes. To ensure the accuracy and consistency of the correction method utilized for correcting the papers, the researchers calculated the inter-rater reliability for the students' written productions at pre-test through coding $25 \%$ of the written data regarding writing accuracy (i.e., grammar) with the help of a research assistant. A high inter-rater reliability was established (r $=0.78)$.

\subsubsection{Post-test}

Finally, the researchers administered the post-test to find out whether CF was effective or not. The test comprised the topic used in the pre-test phase. Also, the inter-rater reliability was calculated for immediate post-test through double rating $25 \%$ of the written data by another research assistant. The inter-rater reliability was high $(r=0.78)$.

\subsection{Procedure}

During the study, 6 advanced classes were selected and the participants were assigned into three groups, namely, direct comprehensive (unfocused) $\mathrm{CF}$, direct selective (focused) $\mathrm{CF}$, and no correction. Then, all three groups were randomly divided into two classes writing collaboratively and individually. Prior to any treatment, the researchers made statistically sure that the participants were not significantly different from each other at the outset of the study. To this end, participants wrote the first composition on a topic selected by the researchers which was considered as both the test of writing homogeneity and pre-test. All 6 groups wrote one composition during 9 sessions on general topics covered in their students' books. They were asked to write compositions within a word limit of at least 250 for Advanced level in 45 minutes. First of all, the researchers focused targeted grammatical structures and the topics (e.g., What does your mother say about her childhood? What would she have done if she had come back?). During writing time, the teacher monitored and observed the learners and provided hints whenever needed.

Learners doing their first composition that served the purpose of pre- and post-test were not allowed to have access to any resources and assistance. Participants' writings were reacted by the teacher following three methods. The teacher underlined all the grammar errors in the written performance of the first group, that is, comprehensive CF. As for the second group, the researchers focused on targeted structures; namely, Reported Speech and Conditional Type (III) (i.e., selective $\mathrm{CF}$ ). However, the third group did not receive any correction from the teacher and were just commented on the content through such terms as great, good, ok, etc.

When the researchers gave back the papers to the learners, learners in the first group (i.e., comprehensive feedback) were given 25 minutes to individually check and reckon the errors corrected directly and underlined by teacher and those in the paired groups did this in pairs as well. And those in the second group (i.e., selective feedback) were given 15 minutes to check the errors corrected by the teacher in both groups (i.e., collaborative and individual). Due to the lack of correction, learners in the third group were required to only take a look at the comments (e.g., good, ok, 
acceptable, etc.) provided by the teacher. This procedure was followed for 9 sessions and at the tenth session, the posttest was conducted for all learners.

\subsection{Data Analysis}

A series of one-way ANOVA statistics were conducted at the pretest to establish homogeneity across the participants and in the post-test to figure out the possible effects of various treatment patterns. Moreover, Post hoc comparison by means of the Tukey HSD test was conducted in post-test stage to find out where exactly the difference/s among the pairs existed. Furthermore, a set of independent samples t-test was run to explore the difference between the collaborative and individual writings in the post-test.

\section{Results}

\subsection{Differences among CF Types in Pre-test}

A one-way analysis of variance was used to explain the homogeneity of the participants at pre-test after the assumptions for parametric tests were met and no violations were detected. The outcome is illustrated in Table 1.

Table 1. Descriptive statistics of the three CF treatment groups in pre-test

\begin{tabular}{|c|c|c|c|c|c|c|c|c|}
\hline \multirow{2}{*}{ Type } & \multirow[b]{2}{*}{$\mathrm{N}$} & \multirow[b]{2}{*}{ Mean } & \multirow[b]{2}{*}{$\begin{array}{l}\text { Std. } \\
\text { Deviation }\end{array}$} & \multirow[b]{2}{*}{ Std. Error } & \multicolumn{2}{|c|}{$\begin{array}{l}95 \% \text { Confidence } \\
\text { Interval for Mean }\end{array}$} & \multirow[b]{2}{*}{ Minimum } & \multirow[b]{2}{*}{ Maximum } \\
\hline & & & & & $\begin{array}{l}\text { Lower } \\
\text { Bound }\end{array}$ & $\begin{array}{l}\text { Upper } \\
\text { Bound }\end{array}$ & & \\
\hline Selective & 22 & 80.87 & 5.0497 & 1.07662 & 78.6397 & 83.117 & 70.00 & 89.00 \\
\hline Comprehensive & 22 & 81.72 & 5.7228 & 1.22012 & 79.1872 & 84.261 & 68.00 & 89.33 \\
\hline No-Correction & 22 & 82.10 & 6.9907 & 1.49043 & 79.0087 & 85.207 & 69.00 & 97.00 \\
\hline Total & 66 & 81.57 & 5.9056 & .72693 & 80.1187 & 83.022 & 68.00 & 97.00 \\
\hline
\end{tabular}

According to the mean scores, there was no outstanding difference among the three groups at pre-test and a one-way analysis of variance (ANOVA) was employed to confirm it (Table 2).

Table 2. ANOVA results: Homogeneity measures in pre-test

\begin{tabular}{llllll}
\hline & Sum of Squares & Df & Mean Square & F & Sig. \\
\hline Between Groups & 17.413 & 2 & 8.707 & .244 & .78 \\
Within Groups & 2249.570 & 63 & 35.707 & & \\
Total & 2266.983 & 65 & & & \\
\hline
\end{tabular}

The results of ANOVA revealed that there were no significant differences $(F=.24, p=.78>.05)$ among the advanced EFL learners who were assigned into three CF treatment groups (i.e., selective, comprehensive, and no correction) at the pre-test stage.

\subsection{Differences among CF Types in Post-test}

Table 3 shows descriptive statistics for differences between the types of written CF in terms of their effect on EFL learners' accuracy development. 
Table 3. Descriptive statistics for the differences among CF types in post-test

\begin{tabular}{|c|c|c|c|c|c|c|c|c|}
\hline \multirow{2}{*}{ Type } & \multirow[b]{2}{*}{$\mathrm{N}$} & \multirow[b]{2}{*}{ Mean } & \multirow[b]{2}{*}{$\begin{array}{l}\text { Std. } \\
\text { Deviation }\end{array}$} & \multirow[b]{2}{*}{ Std. Error } & \multicolumn{2}{|c|}{$\begin{array}{l}95 \% \text { Confidence } \\
\text { Interval for Mean }\end{array}$} & \multirow[b]{2}{*}{ Minimum } & \multirow[b]{2}{*}{ Maximum } \\
\hline & & & & & Lower Bound & $\begin{array}{l}\text { Upper } \\
\text { Bound }\end{array}$ & & \\
\hline Selective & 22 & 55.67 & 6.9291 & 1.47730 & 52.6028 & 58.747 & 45.00 & 67.00 \\
\hline Comprehensive & 22 & 68.74 & 6.0938 & 1.29922 & 66.0463 & 71.450 & 57.00 & 84.20 \\
\hline No-Correction & 22 & 82.78 & 6.0369 & 1.28707 & 80.1129 & 85.466 & 65.00 & 92.00 \\
\hline Total & 66 & 69.07 & 12.7966 & 1.57516 & 65.9251 & 72.216 & 45.00 & 92.00 \\
\hline
\end{tabular}

As the mean scores indicate, there was a difference among three groups in the post-test that was signified through a one-way analysis of variance (Table 4).

Table 4. ANOVA results for the differences among CF types in post-test

\begin{tabular}{llllll}
\hline & Sum of Squares & df & Mean Square & F & Sig. \\
\hline Between Groups & 8090.621 & 2 & 4045.311 & 99.808 & .00 \\
Within Groups & 2553.445 & 63 & 40.531 & & \\
Total & 10644.067 & 65 & & & \\
\hline
\end{tabular}

The results of ANOVA indicated that there was a statistically significant difference $(F=99.80, p=0.00<0.05)$ among three groups at post-test. The group receiving selective feedback outperformed the two other groups. In addition, in order to show the exact points of variations among the groups, a Tukey post-hoc test was run (Table 5).

Table 5. Multiple comparisons for the differences among CF types in post-test

\begin{tabular}{llllllc}
\hline & & & & \multicolumn{2}{l}{$95 \%$ Confidence Interval } \\
(I) Type & (J) Type & $\begin{array}{l}\text { Mean } \\
\text { Difference (I-J) Std. Error }\end{array}$ & Sig. & Lower Bound & Upper Bound \\
\hline Selective & Comprehensive & $-13.07318^{*}$ & 1.91954 & .000 & -17.6807 & -8.4657 \\
& No-Correction & $-27.11455^{*}$ & 1.91954 & .000 & -31.7221 & -22.5070 \\
Comprehensive & Selective & $13.07318^{*}$ & 1.91954 & .000 & 8.4657 & 17.6807 \\
& No-Correction & $-14.04136^{*}$ & 1.91954 & .000 & -18.6489 & -9.4338 \\
& Selective & $27.11455^{*}$ & 1.91954 & .000 & 22.5070 & 31.7221 \\
& Comprehensive & $14.04136^{*}$ & 1.91954 & .000 & 9.4338 & 18.6489 \\
\hline
\end{tabular}

\footnotetext{
*. The mean difference is significant at the 0.05 level.
} 
Multiple comparisons test indicated that there was a difference among groups in post-test. The results of Tukey test indicated that there was a decrease in learners' errors from pre-test to post-test in selective and comprehensive groups compared to no correction group; however, the selective type was the most influential. Figure 1 indicates the distribution of the means.

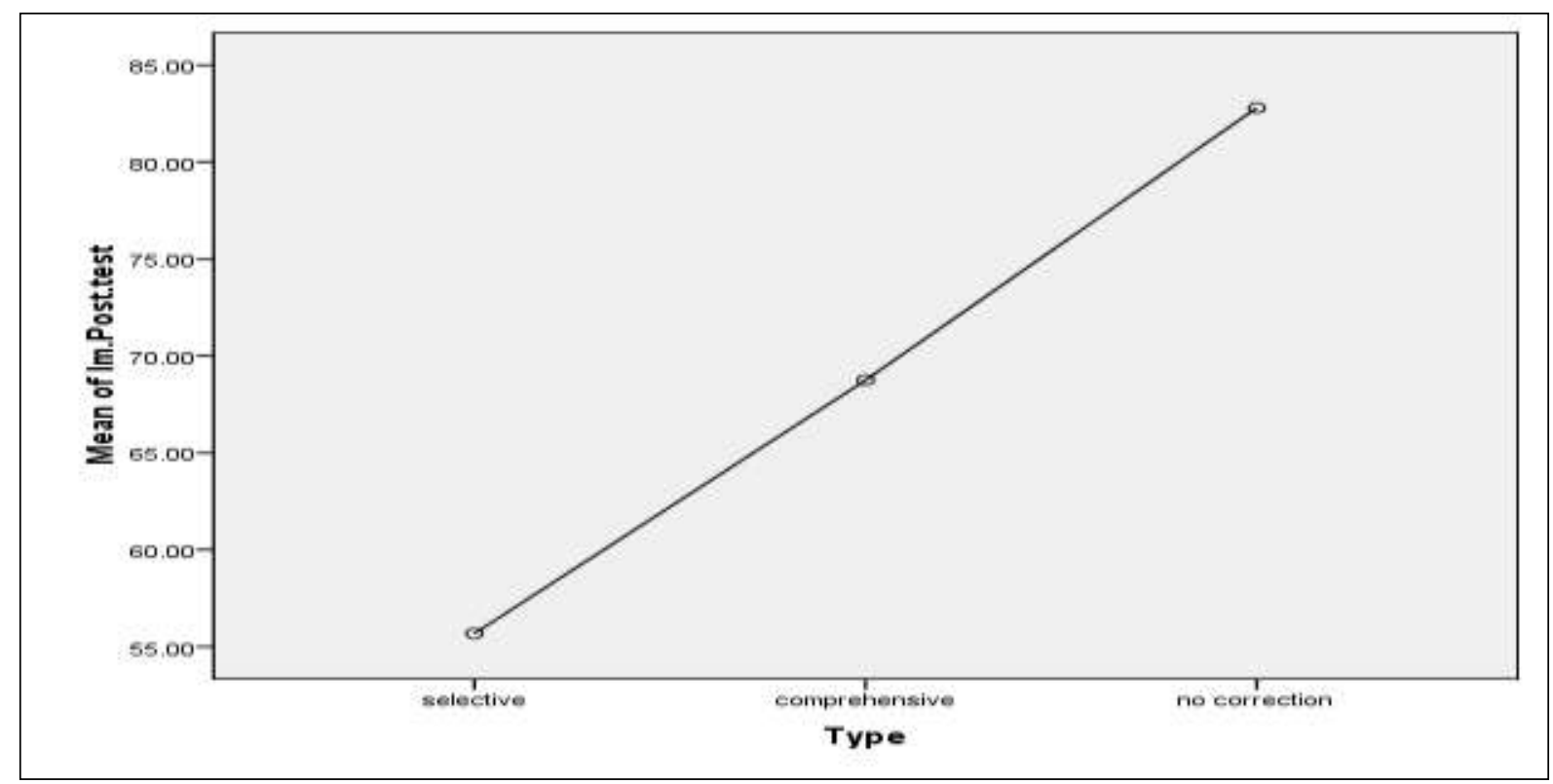

Figure 1. Means plot for the differences among $\mathrm{CF}$ types in post-test

The mean plot indicated that there was a decrease in the number of the errors of the learners' receiving selective feedback.

\subsection{Differences among CF Types in Collaborative Writing in Pre-test}

The influence of CF types was also scrutinized as far as writing accuracy of learners, this time writing in pairs, was concerned. Table 6 shows descriptive statistics related to outcomes of the three groups (selective, comprehensive, and no correction) at pre-test. The main reason was to establish homogeneity among learners .

Table 6. Descriptive statistics for the differences among CF types in pre-test

\begin{tabular}{|c|c|c|c|c|c|c|c|c|}
\hline \multirow{2}{*}{ Type } & \multirow[b]{2}{*}{$\mathrm{N}$} & \multirow[b]{2}{*}{ Mean } & \multirow[b]{2}{*}{$\begin{array}{l}\text { Std. } \\
\text { Deviation }\end{array}$} & \multirow[b]{2}{*}{ Std. Error } & \multicolumn{2}{|c|}{$\begin{array}{l}95 \% \text { Confidence } \\
\text { Interval for Mean }\end{array}$} & \multirow[b]{2}{*}{ Minimum } & \multirow[b]{2}{*}{ Maximum } \\
\hline & & & & & $\begin{array}{l}\text { Lower } \\
\text { Bound }\end{array}$ & $\begin{array}{l}\text { Upper } \\
\text { Bound }\end{array}$ & & \\
\hline Selective & 22 & 78.265 & 4.04952 & .86336 & 76.4700 & 80.0609 & 71.64 & 87.00 \\
\hline Comprehensive & 22 & 81.129 & 4.50486 & .96044 & 79.1322 & 83.1269 & 74.28 & 89.33 \\
\hline No-Correction & 22 & 79.546 & 5.26029 & 1.12150 & 77.2141 & 81.8786 & 70.00 & 89.56 \\
\hline Total & 66 & 79.647 & 4.71037 & .57981 & 78.4892 & 80.8051 & 70.00 & 89.56 \\
\hline
\end{tabular}


According to the mean scores, there was no outstanding difference among three groups at pre-test and a one-way analysis of variance (ANOVA) was employed to confirm it (Table 7).

Table 7. ANOVA results for the differences among CF types in pre-test

\begin{tabular}{lllccc}
\hline & Sum of Squares & df & Mean Square & F & Sig. \\
\hline Between Groups & 90.568 & 2 & 45.284 & 2.111 & .130 \\
Within Groups & 1351.622 & 63 & 21.454 & & \\
Total & 1442.191 & 65 & & & \\
\hline
\end{tabular}

The results of ANOVA revealed that statistically there was no significant difference $(F=2.11, p=.13>.05)$ among the EFL learners assigned to three written CF (selective, comprehensive, and no correction) treatments groups at pretest.

\subsection{Differences among CF Types in Collaborative Writing in Post-test}

Table 8 shows descriptive statistics for differences between the types of written CF in terms of their effect on EFL learners' accuracy development.

Table 8. Descriptive statistics for the differences among CF types in post-test

\begin{tabular}{|c|c|c|c|c|c|c|c|c|}
\hline & \multirow[b]{2}{*}{$\mathrm{N}$} & \multirow[b]{2}{*}{ Mean } & \multirow[b]{2}{*}{$\begin{array}{l}\text { Std. } \\
\text { Deviation }\end{array}$} & \multirow[b]{2}{*}{$\begin{array}{l}\text { Std. } \\
\text { Error }\end{array}$} & \multicolumn{2}{|c|}{$\begin{array}{l}95 \% \text { Confidence } \\
\text { Interval for Mean }\end{array}$} & \multirow[b]{2}{*}{ Minimum } & \multirow[b]{2}{*}{ Maximum } \\
\hline & & & & & $\begin{array}{l}\text { Lower } \\
\text { Bound }\end{array}$ & $\begin{array}{l}\text { Upper } \\
\text { Bound }\end{array}$ & & \\
\hline Selective & 22 & 36.43 & 3.8694 & .82498 & 34.7180 & 38.1493 & 30.00 & 42.00 \\
\hline Comprehensive & 22 & 37.49 & 4.4170 & .94173 & 35.5334 & 39.4502 & 30.00 & 45.28 \\
\hline No Correction & 22 & 83.65 & 6.6687 & 1.4217 & 80.6951 & 86.6086 & 64.28 & 94.00 \\
\hline Total & 66 & 52.52 & 22.7500 & 2.8003 & 46.9331 & 58.1184 & 30.00 & 94.00 \\
\hline
\end{tabular}

As the mean scores indicate, there was a slight difference among the three groups at post-test. A one-way analysis of variance (ANOVA) was employed to check whether these differences were significant (Table 9).

Table 9. ANOVA results for the differences among CF types in post-test

\begin{tabular}{llllll}
\hline & Sum of Squares & df & Mean Square & F & Sig. \\
\hline Between Groups & 31983.762 & 2 & 15991.881 & 607.627 & .000 \\
Within Groups & 1658.070 & 63 & 26.319 & & \\
Total & 33641.832 & 65 & & & \\
\hline
\end{tabular}


The results of ANOVA indicated that there was a statistically significant difference $(F=607.62, p=.00<.05)$ among three groups at post-test. The group receiving selective feedback outperformed two other groups. Moreover, comprehensive group outperformed no correction group. A Tukey post-hoc test was run in order to show the exact points of variations among the groups (Table 10).

Table 10. Multiple comparisons for the differences among CF types in post-test

\begin{tabular}{lllllll}
\hline & & \multicolumn{2}{l}{} & & \multicolumn{2}{l}{$95 \%$ Confidence Interval } \\
\cline { 5 - 6 }$(\mathrm{I})$ Type & (J) Type & Mean Difference & (I-J) & Std. Error & Sig. & Lower Bound Upper Bound \\
\hline Selective & Comprehensive & -1.05818 & 1.54680 & .774 & -4.7710 & 2.6546 \\
& No Correction & $-47.21818^{*}$ & 1.54680 & .000 & -50.9310 & -43.5054 \\
Comprehensive & Selective & 1.05818 & 1.54680 & .774 & -2.6546 & 4.7710 \\
& No Correction & $-46.16000^{*}$ & 1.54680 & .000 & -49.8728 & -42.4472 \\
No Correction & Selective & $47.21818^{*}$ & 1.54680 & .000 & 43.5054 & 50.9310 \\
& Comprehensive & $46.16000^{*}$ & 1.54680 & .000 & 42.4472 & 49.8728 \\
\hline
\end{tabular}

Multiple comparisons using the Tukey HSD test indicated that there was a difference among groups at post-test. The Tukey test showed that there was a decrease in learners' errors from pre-test to post-test in selective and comprehensive groups more than no correction one. Figure 2 indicates the distribution of the means.

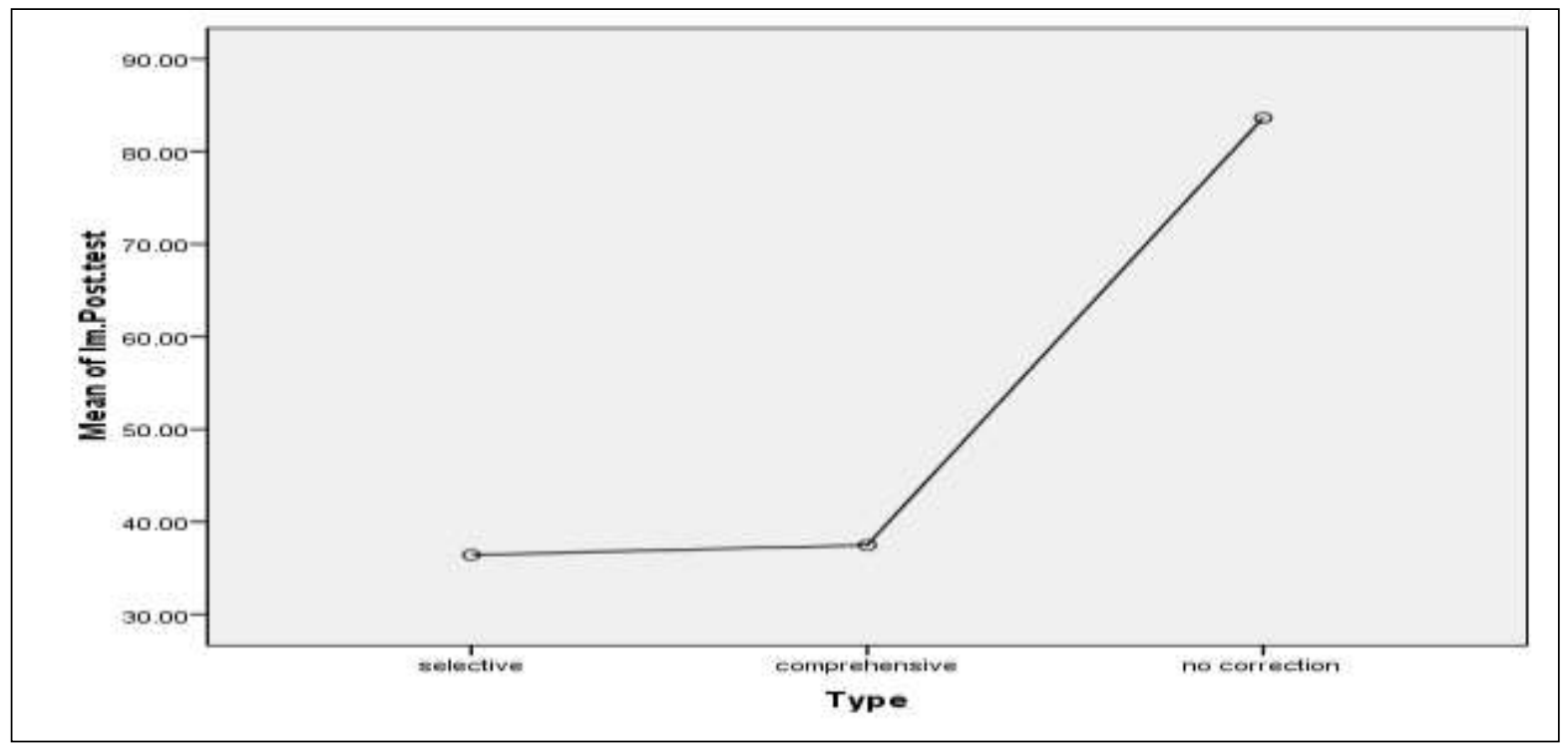

Figure 2. Means plot for the differences among CF types in post-test

The mean plot indicated that there was a decrease in the number of the errors of the learners' receiving selective feedback and comprehensive one; however, the decrease in selective feedback groups was more than those in the comprehensive one. 


\subsection{Difference between Collaborative and Individual Writing Conditions in Post-test}

Table 11 shows descriptive statistics for differences between collaborative and individual writings at the post-test.

Table 11. Descriptive statistics for the difference between collaborative and individual writing conditions in the posttest

\begin{tabular}{llllll}
\hline Levels & Time & $\mathrm{N}$ & Mean & Std. Deviation & Std. Error Mean \\
\hline Advanced & Individual & 66 & 69.07 & 12.79667 & 1.57516 \\
& Collaborative & 66 & 52.52 & 22.75009 & 2.80034 \\
\hline
\end{tabular}

According to the mean scores, there was a difference between collaborative and individual writing conditions.

Table 12. Independent-samples T-test for the difference between collaborative and individual writing conditions in the post-test

\begin{tabular}{|c|c|c|c|c|c|c|c|c|c|c|c|}
\hline & & & \multicolumn{9}{|c|}{$\begin{array}{l}\text { Levene's } \\
\text { Test for } \\
\text { Equality of } \\
\text { Variances t-test for Equality of Means }\end{array}$} \\
\hline & & & \multirow{2}{*}{\multicolumn{2}{|c|}{ Sig }} & \multirow[b]{2}{*}{$\mathrm{t}$} & \multirow[b]{2}{*}{$\mathrm{df}$} & \multirow{2}{*}{$\begin{array}{l}\text { Sig. } \\
(2- \\
\text { tailed } \\
)\end{array}$} & \multirow{2}{*}{$\begin{array}{l}\text { Mean } \\
\text { Difference }\end{array}$} & \multirow{2}{*}{$\begin{array}{l}\text { Std. Error } \\
\text { Difference }\end{array}$} & \multicolumn{2}{|c|}{$\begin{array}{l}95 \% \text { Confidence } \\
\text { Interval of the } \\
\text { Difference }\end{array}$} \\
\hline & & $\mathrm{F}$ & & & & & & & & Lower & Upper \\
\hline \multirow{2}{*}{ Advanced } & $\begin{array}{l}\text { Equal } \\
\text { variances } \\
\text { assumed }\end{array}$ & & 52.3 & .00 & 5.15 & 130 & .00 & 16.545 & 3.212 & 10.188 & 22.90 \\
\hline & $\begin{array}{l}\text { Equal } \\
\text { variances } \\
\text { assumed }\end{array}$ & not & & & 5.15 & 102.3 & .00 & 16.545 & 3.212 & 10.172 & 22.91 \\
\hline
\end{tabular}

According to the independent-samples $t$-test output, there was a significant difference in scores for CW $(M=52.52$, $S D=22.75)$ and individual writing $[M=69.07, S D=12.79 ; t(130)=5.15, p=.00<.05]$ of the learners. In other words, there was an increase in the writing accuracy of the learners writing collaboratively compared to individual ones.

\section{Discussion}

The present study aimed at exploring the effect of various feedback types, that is, direct comprehensive feedback, direct selective feedback, and no feedback on the accuracy of the texts written by EFL learners. In addition, their effect was scrutinized in different writing conditions, that is, individually and collaboratively in order to find ways in helping students to increase their writing accuracy. The results proved the superiority of providing feedback types (i.e., selective and comprehensive). Moreover, in both individual and collaborative writing conditions, selective correction was more effective in decreasing the number of the errors in the post-test. In addition, $\mathrm{CW}$ groups outperformed their peers in the individual groups in terms of writing accuracy development in the post-test.

The results of the present study indicated that CF was very influential in enhancing learners' writing accuracy. A number of studies are in line with this study (Ahmadi Shirazi \& Shekarabi, 2014; Karimi, 2014; Maleki \& Eslami, 
2013; Sarkhosh, Farahani, \& Soleimani, 2012; Zarei \& Rahnama, 2013). Although teachers view it as spending a lot of time on learners' writing, for students, error correction is the most important part that will lead to their success as writers (Ashoori Tootkaboni \& Khatib, 2014; Ferris, 2003; Ghandi \& Maghsoudi, 2014). Moreover, other researchers (Bitchener \& Knoch, 2008; Chandler, 2003; Sheen, 2007) claim that CF promotes grammatical accuracy.

The existing theories can account for the findings. From a Noticing Hypothesis perspective, since CF draws learners' attention to their areas of difficulty and releases their minds to process language content, it can be advantageous. However, contrary to what Truscott (1996) advocates, the results of this study proved that error correction is beneficial in writing classes. In other words, teacher's CF is, indeed, effective in helping students reduce their grammatical errors in the post-test.

Regarding the efficacy of selective type of the feedback in this study, the findings are in line with Bitchener and Knoch (2010a) and Pashazadeh and Marefat (2010) who showed that students who had received selective CF continued to outperform students whose errors had not been corrected. Moreover, Sheen et al. (2009) reported that selective CF is more beneficial than comprehensive feedback. It may be that learners had a good understanding of the rules for their usage and only needed the CF to raise their consciousness (Bitchener, 2008; Bitchener \& Knoch, 2008). Regarding theoretical predictions on the use of selective feedback, Pienemann (1989) argues that learners will only be able to acquire linguistic structures for which they show developmental readiness. In other words, CF should be aligned to the learner's current level of L2 development or, as SCT explains, be within their ZPD.

With respect to the effect of $\mathrm{CW}$ on the quality of students' writing accuracy, results of the statistical analysis showed that CW had an overall significant effect on improving students' writing accuracy. Previous research studies also found that learners' writing in pairs produced linguistically more accurate texts than those writing alone (Du, 2018; Storch, 2005, 2011, 2013; Storch \& Wigglesworth, 2007; Wigglesworth \& Storch, 2009). According to Vygotky’s (1978) SCT, learning is a social activity.

Involving the learners in collaborative activities can increase the interaction among learners in the writing class. The collaborative dialogue in the writing process mediates language learning. Supporting the results of this study, Fahim and Haghani (2012) state that learners' personal effort will not result in the mastery of the language without help from other people. Therefore, giving and receiving feedback from peers not only promotes the level of the learners' writing but it also offers them opportunities to communicate with each other, share ideas and give useful comments and suggestions.

\section{Conclusion}

The results of the study justified the positive effect of two CF types, that is, selective and comprehensive especially selective type on the learners' accuracy improvement. Moreover, learners' writing accuracy in CW groups enhanced more than the ones in the individual groups in the post-test. The findings of the present study can be of great benefit to English language teachers in providing learners with feedback types based on the learners' interlanguage development as well as writing conditions. Moreover, EFL instructors are recommended not to rid themselves of the burden of using various CF types in the classes because each type is an important avenue for students to improve their writing accuracy.

From a pedagogical perspective, $\mathrm{CW}$ can be used as a pedagogical tool to encourage student collaboration and create a positive social atmosphere in the classroom. Thus, writing teachers can provide opportunities for students to work collaboratively since more capable students can guide and help the weaker ones. In other words, collaboration encourages students to develop their independence and responsibility to construct knowledge on their own. As any human production, this study has some limitations. A serious limitation of this study was the gender of the participants who were limited to female learners. In addition, the results of this study may be unique to this particular population. In order to gain more reliable information, other studies should be carried out with more participants in different contexts. Moreover, this study focused on the effect of direct CF on the learners' writing accuracy. Moreover, a longitudinal study is required to ensure the efficacy of CF types on the accuracy of the targeted structures in this study as well as other structures. 


\section{References}

Ahmadi Shirazi, M., \& Shekarabi, Z. (2014). The role of written corrective feedback in enhancing the linguistic accuracy of Iranian Japanese learners' writing. Iranian Journal of Language Teaching Research, 2(1), 99118. http://ijltr.urmia.ac.ir/article 20426.html

Araghi, S. M., \& Sahebkheir, F. (2014). The effect of focused versus unfocused corrective feedback on developing grammatical accuracy of Iranian EFL learners' written performance within different gender groups. Indian Journal of Fundamental and Applied Life Sciences, 4(S3), 720-729.

Ashoori Tootkaboni, A., \& Khatib, M. (2014). The efficacy of various kinds of error feedback on improving writing accuracy of EFL learners. Bellaterra Journal of Teaching \& Learning Language \& Literature, 7(3), 30-46. https://revistes.uab.cat/jtl3/article/view/529

Aydin, Z., \& Yildiz, S. (2014). Using wikis to promote collaborative EFL writing. Language Learning \& Technology, 18(1), 160-180.

Batstone, R. (2010). Socio-cognitive perspectives on language use and language learning. Oxford: Oxford University Press.

Bitchener, J. (2008). Evidence in support of written corrective feedback. Journal of Second Language Writing, 17(2), 102-118. https://doi.org/10.1016/j.jslw.2007.11.004

Bitchener, J., \& Knoch, U. (2008). The value of written corrective feedback for migrant and international students. Language Teaching Research Journal, 12(3), 409-431. doi: 10.1177/1362168808089924

Bitchener, J., \& Knoch, U. (2010a). The contribution of written corrective feedback to language development: A ten month investigation. Applied Linguistics, 31(2), 193-214. doi: 10.1093/applin/amp016

Brown, H. D. (2007). Teaching by principles. An interactive approach to language pedagogy. White Plains, NY: Pearson Education.

Celce-Murcia, M. (2001). Teaching English as a second or foreign language. United States: Heinle and Heinle.

Chandler, J. (2003). The efficacy of various kinds of error feedback for improvement in the accuracy and fluency of L2 student writing. Journal of Second Language Writing, 12(3), 267-296. doi: 10.1016/S1060$\underline{3743(03) 00038-9}$

Cheek, D. W. (1992). Thinking constructively about science: Technology and society education. Albany, NY: State University of New York Press.

Corpuz, V. (2011). Error correction in second language writing: Teachers' beliefs, practices, and students' preference (Unpublished doctoral dissertation). Queensland University of Technology, Faculty of Education. http://eprints.qut.edu.au/49160/

Dale, H. (1994). Collaborative writing interactions in one ninth-grade classroom. Journal of Educational Research, 87(6), 334-344. https://doi.org/10.1080/00220671.1994.9941264

Dillenbourg, P. (1999). What do you mean by collaborative learning? In P. Dillenbourg (Ed.), Collaborative-learning: Cognitive and computational approaches. (pp. 1-19). Oxford; UK, Elsevier Publishing.

Du, F. (2018). Comparing students' perceptions and their writing performance on collaborative writing: A case study. English Language Teaching, 11(12), 131-137. doi: 10.5539/elt.v11n12p131

Ellis, R. (2009). A typology of written corrective feedback types. ELT Journal, 63(2), 97-107. doi: 10.1093/elt/ccn023

Ellis, R., Sheen, Y., Murakami, M., \& Takashima, H., (2008). The effects of focused and unfocused written corrective feedback in an English as a foreign language context. System, 36(3), 353-371. https://doi.org/10.1016/j.system.2008.02.001

Fahim, M., \& Haghani, M. (2012). Sociocultural perspectives on foreign language Learning. Journal of Language Teaching and Research, 3(4), 693-699. doi:10.4304/jltr.3.4.693-699 
Ferris, D. (1999). The case of grammar correction in L2 writing classes: A response to Truscott (1996). Journal of Second Language Writing, 8(2), 111-122. https://doi.org/10.1016/S1060-3743(99)80124-6

Ferris, D. (2003). Response to student writing: Implications for second language students. Mahwah, NJ: Erlbaum.

Ferris, D. (2004). The "grammar correction" debate in L2 writing: Where are we, and where do we go from here? (and what do we do in the meantime?). Journal of Second Language Writing, 13(1), 49-62. doi: $10.1016 /$ j.jslw.2004.04.005

Ferris, D. (2006). Does error feedback help student writers? New evidence on the short- and long-term effects of written error correction. In K. Hyland \& F. Hyland (Eds.), Feedback in second language writing: Contexts and issues (pp. 81-104). Cambridge: Cambridge University Press.

Ferris, D. (2010). Second language writing research and written corrective feedback in SLA. Studies in Second Language Acquisition, 32(2), 181-201. doi: https://doi.org/10.1017/S0272263109990490

Ferris, D. R., Pezone, S., Tade, C. R., \& Tinti, S. (1997). Teacher commentary on student writing: Descriptions and implications. Journal of Second Language Writing, 6(2), 155-182. https://doi.org/10.1016/S1060$\underline{3743(97) 90032-1}$

Fung, M. Y. (2011). Improving ESL learners' academic text construction through a collaborative task. Pertanika Journal of Social Science \& Humanities, 19(2), 475-485. https://core.ac.uk/download/pdf/153806894.pdf

Ghandi, M., \& Maghsoudi, M. (2014). The effect of direct and indirect corrective feedback on Iranian ELF learners' spelling errors. English Language Teaching, 7(8), 53-61. doi:10.5539/elt.v7n8p53

Ghoorchaei, B., Tavakoli, M., \& Nejad Ansari, D. (2010). The impact of portfolios assessment on Iranian EFL students' essay writing: A process-oriented approach. Journal of Language Studies, 10(3), 35-51. http://journalarticle.ukm.my/2335/1/page1_21.pdf

Godwin-Jones, R. (2018). Second language writing online: An update. Language Learning \& Technology, 22(1), 115. https://eric.ed.gov/?id=EJ1168899

Gousseva-Goodwin, J. V. (2000). Collaborative writing assignments and on-line Discussions in An advanced ESL composition class (Unpublished doctoral dissertation). University of Arizona, USA.

Hyland, K., \& Hyland, F. (2006). Feedback on second language students' writing. Language Teaching, 39(2), 83-101. doi: https://doi.org/10.1017/S0261444806003399

Kahyalar, E., \& Y1lmaz, F. (2016). Teachers' corrective feedback in writing classes: the impact of collaborating with a peer during the editing process on students' uptake and retention. The Reading Matrix: An International Online Journal, 16(1), 148-160. https://eric.ed.gov/?id=EJ1100395

Karimi, M. (2014). The impact of teacher's implicit versus explicit corrective feedback on learning 12 grammar by Iranian English learners. International Journal of Academic Research in Business and Social Sciences, 4(4), 223-234. https://ideas.repec.org/a/hur/ijarbs/v4y2014i4p223-234.html

Koosha, M., \& Yakhabi, M. (2013). Problems associated with the use of communicative language teaching in ELF context and possible solutions. Foreign Language Teaching and Research, 1(2), 63-76. https://pdfs.semanticscholar.org/76c5/454d0d3931e773be58e3804e1e13081ea4dc.pdf

Lalande, J. F. (1982). Reducing composition errors: An experiment. Modern Language Journal, 66(2), 140-149. https://doi.org/10.1111/j.1540-4781.1982.tb06973.x

Lantolf, J. (2000). Sociocultural theory and second language learning. Oxford: Oxford University Press.

Lee, M. K. (2015). Peer feedback in second language writing: Investigating junior secondary students' perspectives on inter-feedback and intra-feedback. System, 55, 1-10. https://doi.org/10.1016/j.system.2015.08.003

Li, S. (2010). The effectiveness of corrective feedback in SLA: A meta-analysis. Language Learning, 60(2), 309-365. https://doi.org/10.1111/j.1467-9922.2010.00561.x 
Li, M., \& Zhu, W. (2017). Good or bad collaborative wiki writing: Exploring links between group interactions and writing products. Journal of Second Language Writing, 35, 38-53. https://doi.org/10.1016/j.jslw.2017.01.003

Lightbown, P. M., \& Spada, N. (2006). How languages are learned (3rd ed.). Oxford: Oxford University Press.

Long, M. H. (1996). The role of the linguistic environment in second language acquisition. In W. C. Ritchie, \& T. K. Bhatia (Eds.), Handbook of language acquisition second language acquisition. New York: Academic Press.

Lyster, R., \& Saito, K. (2010). Oral feedback in classroom SLA: A meta-analysis. Studies in Second Language Acquisition, 32(2), 265-302. doi: https://doi.org/10.1017/S0272263109990520

Mackey, A., \& Goo, J. (2007). Interaction research in SLA: A meta-analysis and research synthesis. In A. Mackey (Ed.), Conversational interaction in second language acquisition: A series of empirical studies (pp. 407-452). Oxford: Oxford University Press.

Maleki, A., \& Eslami, E. (2013). The effects of written corrective feedback techniques on EFL students' control over grammatical construction of their written English. Theory and Practice in Language Studies, 3(7), 1250-1257. doi: $10.4304 /$ tpls.3.7.1250-1257

McDonough, K. (2004). Learner-learner interaction during pair and small group activities in a Thai EFL context. System, 32(2), 207-224. https://doi.org/10.1016/j.system.2004.01.003

Mozaffari, S. H. (2017). Comparing student-selected and teacher-assigned pairs on collaborative writing. Language Teaching Research, 21(4), 496-516. https://doi.org/10.1177/1362168816641703

Pashazadeh, A., \& Marefat, H. (2010). The long-term effect of selective written grammar feedback on EFL learners' acquisition of articles. Pazhuhesh-e Zabanha-ye Khareji, 56, 49-67. https://jor.ut.ac.ir/article_20556_42ea1c8f7a45da1f1263ef29270209af.pdf

Pienemann, M. (1989). Is language teachable? Applied Linguistics, 10(1), 52-79. https://doi.org/10.1093/applin/10.1.52

Salimi, A., \& Ahmadpour, M. (2015). The effect of direct vs. indirect written corrective feedback on L2 learners' written accuracy in EFL context. International Journal of English Language and Literature Studies, 4(1), 1019. doi: $10.18488 /$ journal.23/2015.4.1/23.1.10.19

Sarkhosh, M., Farahani, A. K., \& Soleimani, M. (2012). Different types of corrective feedback and the improvement of the accuracy in the use of English simple past. The Iranian EFL Journal, 8(6), 258-280. https://www.researchgate.net/publication/333420529

Sheen, Y. (2007). The effect of focused written corrective feedback and language aptitude on ESL learners' acquisition of articles. TESOL Quarterly, 41(2), 255-283. https://doi.org/10.1002/j.1545-7249.2007.tb00059.x

Sheen, Y., Wright, D., \& Moldawa, A. (2009). Differential effects of focused and unfocused written correction on the accurate use of grammatical forms by adult ESL learners. System, 37(4), 556-569. https://doi.org/10.1016/j.system.2009.09.002

Shehadeh, A., \& Coombe, C. (2010). Applications of task-based learning in TESOL. Alexandria, VA: TESOL.

Stewart, D. (1988). Collaborative learning and composition: boon or bane? Rhetoric Review, 7(1), 58-83. https://doi.org/10.1080/07350198809388840

Storch, N. (2005). Collaborative writing: Product, process, and students' reflections. Journal of Second Language Writing, 14(3), 153-173. https://doi.org/10.1016/j.jslw.2005.05.002

Storch, N. (2011). Collaborative writing in L2 contexts: Processes, outcomes, and future directions. Annual Review of Applied Linguistics, 31, 275-288. doi: https://doi.org/10.1017/S0267190511000079

Storch, N. (2013). Collaborative writing in L2 classrooms. Bristol, UK: Multilingual Matters.

Storch, N., \& Wigglesworth, G. (2007). Writing tasks: The effects of Collaboration. In M. Garc1'a Mayo (Ed.), Investigating tasks in formal language learning (pp. 157-177). Clevedon, UK: Multilingual Matters. 
Swain, M., \& Lapkin, S. (1998). Interaction and second language learning: Two adolescent French immersion students working together. Modern Language Journal, 82(3), 320-337. https://doi.org/10.1111/j.1540$\underline{\text { 4781.1998.tb01209.x }}$

Tocalli-Beller, A. (2003). Cognitive conflict, disagreement and repetition in collaborative groups: Affective and social dimensions from an insider's perspective. The Canadian Modern Language Review, 60(2), 143-172. https://doi.org/10.3138/cmlr.60.2.143

Truscott, J. (1996). The case against grammar correction in L2 writing classes. Language Learning, 46(2), 327-369. https://doi.org/10.1111/j.1467-1770.1996.tb01238.x

Truscott, J. (1999). The case for "The case against grammar correction in L2 writing classes": A response to Ferris. Journal of Second Language Writing, 8(2), 111-122. https://doi.org/10.1016/S1060-3743(99)80124-6

Truscott, J. (2007). The effect of error correction on learners' ability to write accurately. Journal of Second Language Writing, 16(4), 255-272. https://doi.org/10.1016/j.jslw.2007.06.003

Truscott, J., \& Hsu, A. (2008). Error correction, revision, and learning. Journal of Second Language Writing, 17(4), 292-305. https://doi.org/10.1016/j.jslw.2008.05.003

Van Beuningen, C. (2010). Corrective feedback in L2 writing: Theoretical perspectives, empirical insights, and future directions. International Journal of English Studies, 10(2), 1-27. doi: https://doi.org/10.6018/ijes/2010/2/119171

Van Beuningen, C., De Jong, N., \& Kuiken, F. (2008). The effect of direct and indirect corrective feedback on L2 learners' written accuracy. ITL International Journal of Applied Linguistics, 156(1), 279-296. doi: https://doi.org/10.2143/ITL.156.0.2034439

Van Beuningen, C., De Jong, N., \& Kuiken, F. (2012). Evidence on the effectiveness of comprehensive error correction in second language writing. Language Learning, 62(1), 1-41. https://doi.org/10.1111/j.14679922.2011.00674.x

Villamil, O. S., \& de Guerrero, M. C. M. (1998). Assessing the impact of peer revision in L2 writing. Applied Linguistics, 19(4), 491-514. https://doi.org/10.1093/applin/19.4.491

Vygotsky, L. (1978). Mind in society: The development of higher psychological processes. Cambridge, MA: Harvard University Press.

Wigglesworth, G., \& Storch, N. (2009). Pair versus individual writing: Effects on fluency, complexity and accuracy. Language Testing, 26(3), 445-466. https://doi.org/10.1177/0265532209104670

$\mathrm{Wu}, \mathrm{H}$. (2015). The effects of blog-supported collaborative writing on writing performance, writing anxiety and perceptions of EFL college students in Taiwan (Unpublished $\mathrm{PhD}$ thesis, The University of South Florida, USA).

Yager, R. (1991). The constructivist learning model, towards real reform in science education. The Science Teacher, 58(6), 52-57. doi: 10.2307/24146213 https://www.jstor.org/stable/24146213

Zarei, A. A., \& Rahnama, M. R. (2013). The effect of written corrective feedback modes on ELF learners' grammatical and lexical writing accuracy: From perceptions to facts. International Journal on Studies in English Language $\begin{array}{llll}\text { and } \quad \text { Literature } & \text { (IJSELL), } & 1-14 .\end{array}$ file://C:/Users/ASUS/AppData/Local/Temp/The_Effect_of_Written_Corrective_Feedbac.pdf

Zhang, M. X. (2018). Collaborative writing in the EFL classroom: The effects of L1 and L2 use. System, 76, 1-12. https://doi.org/10.1016/j.system.2018.04.009

Zheng, B., \& Warschauer, M. (2017). Epilogue: Second language writing in the age of computer-mediated communication. Journal of Second Language Writing, 36, 61-67. https://doi.org/10.1016/j.jslw.2017.05.014 